\title{
Temporal trends in energy and macronutrient distribution in meals eaten by children from the Avon Longitudinal Study of Parents and Children
}

\author{
Suzana Almoosawi Newcastle University, UK \\ suzana.almoosawi@newcastle.ac.uk

\begin{tabular}{ll}
\hline Victoria Cribb & Bristol University, UK \\
Pauline Emmett & Bristol University, UK
\end{tabular} \\ Alison Lennox University of Surrey, UK
}

(Received February 2014 Revised September 2015)

http://dx.doi.org/10.14301/llcs.v7i1.292

\section{Abstract}

Cross-sectional studies have reported associations between frequency of eating, snacking, breakfast skipping, night-eating and obesity. However, there have been few investigations of longitudinal trends in time-of-day of energy and macronutrient intake. We investigated trends in time-of-day of energy and macronutrient intake in the Avon Longitudinal Study of Parents and Children. Diet was assessed using 3d estimated diaries at ages 10 and 13 years. Diaries were divided into seven time slots: breakfast, mid-morning, lunch, mid-afternoon, dinner, late evening and extras. Trends in energy and macronutrient intake at different eating occasions between ages 10 and 13 years were assessed using linear mixed models after adjustment for age, maternal employment and child's BMI. Lunch and dinner were found to contribute the greatest proportion of energy and macronutrient intake in both girls and boys at both ages. However, there was a shift in time-of-day of energy and macronutrient intake for both sexes, with greater proportions of intake between meals (mid-morning, late evening, extras) and lower proportion of intake at main meals (breakfast, dinner) at age 13 years compared to 10 years. Factors contributing to changes in energy and nutrient distribution warrant investigation and the implications of such changes in time-of-day of energy and nutrient intake on long-term health remains to be examined.

\section{Keywords}

Circadian rhythm, eating profile, eating pattern, time-of-day, energy, macronutrients, ALSPAC, prospective study

\section{Introduction}

It is increasingly recognised that the time, nutrient composition (Bray et al. 2010; Cho, Dietrich, Brown, Clark \& Block, 2003; DeshmukhTaskar, Nicklas, Radcliffe, O'Neil \& Liu, 2012; Deshmukh-Taskar et al., 2010), frequency (Farshchi, Taylor \& Macdonald, 2005a, 2005b) and regularity of meals (Farshchi et al. 2005a; Sierra-Johnson et al., 2008) can influence multiple metabolic parameters and consequently health (Almoosawi, Prynne, Hardy \& Stephen, 2012; Almoosawi, Prynne, Hardy \& Stephen, 2013a, 2013b). In both children and adults, skipping breakfast is associated with poorer micronutrient intake, poorer growth 
and increased weight and body fatness (DeshmukhTaskar, Nicklas, Radcliffe, O'Neil \& Liu, 2012; Deshmukh-Taskar et al., 2010; Hallstrom et al., 2012; Rampersaud, Pereira, Girard, Adams \& Metzl, 2005), while regular breakfast consumption is associated with lower body fatness and improved lipid, blood pressure and glucose profiles especially in boys (Hallstrom et al., 2012). The composition of breakfast has also been shown to influence total daily energy intake and weight (Cho, et al., 2003; Deshmukh-Taskar, Nicklas, Radcliffe, O’Neil \& Liu, 2012) and cognitive performance at school (Mahoney, Taylor, Kanarek \& Samuel, 2005), while eating after dinner has been related to multiple cardiometabolic risk factors and obesity (Almoosawi et al., 2013b; Sato et al., 2011). Thus, examining recent trends in energy and macronutrient distribution is important in contributing to our understanding of the role of time-of-day of eating on recent trends in obesity and other disorders.

The transition between childhood and adolescence marks a key stage in human development, and is characterised by multiple physiological, psychological and behavioural changes. Increased independence, concerns of body image and social activities outside the home can influence decisions regarding what and when to eat. In girls, the quality of the diet appears to decline (Mannino, Lee, Mitchell, Smiciklas-Wright \& Birch, 2004) and the prevalence of breakfast skipping increases to a greater extent than in boys (Keski-Rahkonen, Kaprio, Rissanen, Virkkunen, \& Rose 2003) with the move into teenage years. Dietary habits are known to track from adolescence to adulthood (Mannino et al., 2004; te Velde, Twisk \& Brug, 2007). Consequently, poor eating patterns in adolescence can carry implications for health and disease development in adulthood. Despite this evidence, few studies have examined trends in energy and nutrient distribution through the day in children through their transition to adolescence.

The present paper aims to describe energy and macronutrient distribution across different eating occasions in the Avon Longitudinal Study of Parents and Children (ALSPAC). It will present data on the proportion of consumers and non-consumers within given eating occasions, and examine changes in time-of-day of energy and macronutrient intake across eating occasions between the ages of 10 and 13 years.

\section{Methods}

The Avon Longitudinal Study of Parents and Children (ALSPAC) is an on-going UK longitudinal cohort study which is designed to investigate the health and development of children. The study recruited 14,541 pregnant women resident in the former Avon Health Authority in South West England with expected delivery date between April 1991 and December 1992. This resulted in 13,988 children alive at 12-months, with an additional 548 new participants being recruited at age seven years giving a total of 14,536 children. Ethical approval for the study was obtained from the ALSPAC Law and Ethics Committee and the Local Research Ethic Committees. Details of the study have been published previously (Boyd et al., 2013). Please note that details of all ALSPAC data is available through a fully searchable data dictionary at http://www.bris.ac.uk/alspac/researchers/dataaccess/data-dictionary/

\section{Dietary assessment}

Detailed dietary assessments were carried out in the period between February 2002 and October 2003 (mean age 10.6 years), and January 2005 and September 2006 (mean age 13.8 years). Details of the dietary assessment method have been described elsewhere (Emmett, 2009). Briefly, prior to a clinic visit, children were asked, with the help of their carer to record all food and drinks consumed in a structured three-day diet diary (two weekdays and one weekend day) that was subdivided into eight eating occasions: prebreakfast, breakfast, mid-morning, lunch, midafternoon, dinner, late evening and extras. Children were asked to describe portions using household measures. If the description was inadequate a portion size was allocated based on data on average portion sizes consumed by children of the same age derived from weighed dietary intakes (Wrieden et al., 2008) from a national survey of British children (Gregory, Collins, Davies, Hughes \& Clarke, 1995; Gregory \& Lowe, 2000). Further portion size information was obtained from manufacturers. Overall, 3,320 children completed three-day diet diaries (1,561 boys and 1,759 girls) at both ages 10 and 13 years, representing $23 \%$ of entire cohort, $44 \%$ of those with any dietary data collected at 10 years and $54 \%$ at 13 years. Children who completed dietary assessment at both time-points were more likely to have mothers with higher 
education levels compared to those who did not complete assessment at both time-points. Diet records were coded using DIDO (Diet In, Data Out) developed by the Dunn Nutrition Unit in Cambridge (Emmett, 2009), and nutrient analysis used the $5^{\text {th }}$ edition of McCancee and Widdowson's "The Composition of Foods" (Holland et al., 1991) and supplements (Chan, Brown \& Buss, 1994; Chane, Brown, Lee \& Buss, 1995; Holland, Unwin \& Buss, 1991; Holland, Unwin \& Buss, 1988; Holland, Unwin \& Buss, 1989; Holland, Welsh \& Buss, 1992a, 1992b; Holland, Brown \& Buss, 1993).

\section{Maternal employment, child \\ anthropometry and mis-reporting}

The above variables have been selected as potential confounders. Maternal employment has been previously shown to influence children's meal regularity and meal skipping (Gaina, Sekine, Chandola, Marmot \& Kagamimori, 2009). Similarly, overweight and obese children appear to differ in their eating patterns and time-of-energy intake through the day compared to lean children (Bellisle, Rolland-Cachera, Deheeger \& Guilloud-Bataille, 1988). Finally, there is evidence to suggest that mis-reporting can be selective with between-meal snacks more frequently under-reported (Poppitt, Swann, Black \& Prentice, 1998). Maternal employment status was derived from a questionnaire completed when the child was aged 122-months (10.2 years). The question asked 'how many hours were worked in the last week?'. In this analysis maternal employment was grouped as minimal working (less than seven hours), part-time (seven-28 hours) and full-time (more than 28 hours). Mis-reporting was estimated using an individualised method as the ratio of reported energy intake to estimated energy requirements (Rennie, Coward \& Jebb, 2007). Children with an energy intake to estimated energy requirement ratio between $0.79-1.21$ were deemed as normal reporters (Johnson, Mander, Jones, Emmett \& Jebb, 2008). Overall of the 3,321 children, 1,079 and 2,000 were found to under-report energy intake at age 10 and 13 years, respectively.

At the research clinic visit at ages 10 and 13 years, trained staff collected data on height, weight, waist circumference, and body composition. Height was measured to the last complete millimeter using the Harpenden Stadiometer and weight measured to the nearest $50 \mathrm{~g}$ using the Tanita Body Fat
Analyser (Model TBF 305). BMI was calculated as weight in kilograms divided by the square of height in meters. Underweight, overweight and obesity were defined using age and sex specific cut-off points from the International Obesity Task Force (Cole, Bellizzi, Flegal \& Dietz, 2000; Cole, Flegal, Nicholls \& Jackson, 2007).

\section{Statistical analyses}

Changes in proportion of consumers and nonconsumers were assessed using McNemar's chisquare statistics. Multilevel models were used to investigate changes in the trajectory of energy or macronutrient intake at different eating occasions in boys and girls between ages 10 and 13years after adjustment for age, child's BMI and maternal employment. A random intercept and slope model was selected to allow each child to have their own intercept and slope. Age was centred at the mean in order to facilitate interpretation of the model intercept, without affecting the interpretation of the slope. Likelihood ratio tests were used to compare the multilevel models to a null single-level model. The advantage of using a random-effects model is that such models can separate betweensubject variations from longitudinal changes and allow for missing data. All models were fitted separately for boys and girls. Additional analyses assessing differences in macronutrient intake between main meals (breakfast, lunch and dinner) and between-meal eating occasions (mid-morning, mid-afternoon, late evening and extras) were conducted including type of eating occasion as a binary predictor variable in the multilevel models. Sensitivity analysis including children with only accurate energy reporting were conducted. All statistical analyses were performed using STATA 13 and IBM SPSS version 21.

\section{Results}

\section{Trends in energy intake}

The distribution of energy and macronutrients by eating occasion in boys and girls at ages 10 and 13 years is shown in Table 1 for the entire sample, including non-consumers of particular eating occasions, and in table 2 for the sample excluding non-consumers. The percentage of non-consumers was higher at age 13 years at breakfast, midafternoon and dinner than at 10 years in both boys and girls, while the percentage of non-consumers 
declined at mid-morning and for extras (figure 1). In girls, the percentage of non-consumers decreased in the late evening eating occasion between ages 10 and 13 years.

After adjustment for BMI and maternal employment, mean proportion of energy intake at age 10 years at breakfast was $16.5 \%$ for boys and $16.1 \%$ for girls (table 3 ). This proportion declined by $1.9 \%$ and $2.6 \%$ between ages 10 and 13 years for boys and girls, respectively. At child level, mean proportion of energy intake at breakfast varied with a standard deviation (SD) of 3.69 and 3.66, while the rate of change varied with a SD of 2.82 and 0.13 for both boys and girls, respectively. These random effects remained highly correlated, so children who obtained a high proportion of energy intake from breakfast at age 10 years tended to have lower rate of decline over time.

Lunch and dinner continued to contribute the greatest proportion of total daily energy intake at both ages 10 and 13 years. Mean proportion of energy intake at age 10 years at lunch was $28.2 \%$ for boys and $30.5 \%$ for girls. This declined at a rate of $2.2 \%$ for boys and $2.8 \%$ for girls, respectively between ages 10 and 13 years. At child level, mean proportion of energy intake at lunch varied with a SD of 3.35 for boys and 2.47 for girls, respectively, while the rate of change varied with a SD of 0.29 for boys and $3.9 \%$ for girls, respectively. These random effects remained highly correlated, so children who obtained a high proportion of energy intake from lunch at age 10 years tended to have a lower rate of decline over time. Mean proportion of energy intake at dinner at age 10 years was $28.7 \%$ for boys and $27.6 \%$ for girls. This declined at a rate of $2.9 \%$ and $2.0 \%$ between ages 10 and 13 years for boys and girls, respectively. At child level, mean proportion of energy intake at dinner varied with a SD of 4.48 and 4.03 , while the rate of change varied with a SD of 3.38 and 2.24 for both boy and girls, respectively. In relation to boys, the random effects did not correlate after adjustment for individual level covariates, suggesting that a boy's BMI or maternal employment accounted for most of the variation. In relation to girls, the random effects remained highly correlated, so girls who obtained a high proportion of energy intake from dinner at age 10 years tended to have lower rate of decline over time. Mean proportion of energy intake at age 10 years at dinner was $0.13 \%$ and $0.10 \%$ higher for boy and girls, respectively, for every one unit increase in BMI.

In relation to between-meal eating occasions, mean proportion of energy intake at mid-morning increased at a rate of $3.1 \%$ for boys and $6.3 \%$ for girls, respectively, between ages 10 and 13 years. These random effects remained highly correlated, so children who obtained a high proportion of energy intake from mid-morning at age 10 years tended to have lower rate of decline over time. In relation to boys, mean proportion of energy intake at age 10 years at mid-morning was $0.09 \%$ lower for every one unit increase in BMI.

Mean proportion of energy intake at age 10 years at mid-afternoon was $10.5 \%$ for boys and $9.5 \%$ for girls. This intake declined at a rate of $1.6 \%$ for boys and $2.0 \%$ for girls, respectively, between ages 10 and 13 years. At child level, mean proportion of energy intake at mid-afternoon varied with a SD of 2.50 for boys and 1.90 for girls, respectively, while the rate of change varied with a SD of 3.31 and 0.97 , respectively. These random effects remained highly correlated, so children who obtained a high proportion of energy intake from mid-afternoon at age 10 years tended to have higher rate of decline over time.

Between ages 10 and 13 years, mean proportion of energy intake at late-evening increased at a rate of $3.2 \%$ for boys and $3.3 \%$ for girls, respectively. These random effects remained highly correlated, so children who obtained a high proportion of energy intake from late-evening at age 10 years tended to have lower rate of decline over time.

Mean proportion of energy intake increased at the extra eating occasion at a rate of $2.4 \%$ and $2.9 \%$ between ages 10 and 13 years. Children who obtained a high proportion of energy intake from extras at age 10 years tended to have higher rate of decline over time.

\section{Trends in macronutrient intake}

In general, the distribution of macronutrients followed a similar pattern to that seen for energy (tables 1-2). Data from the linear mixed models are presented as supplementary material. However, the macronutrient composition of eating occasions differed significantly. In boys and girls, the proportion of energy intake from protein increased across all eating occasions between ages 10 and 13 years, with the exception of breakfast and extra eating occasions in girls (figure 2). By contrast, the proportion of energy intake from fat declined at 
lunch in boys and at breakfast, lunch and dinner in girls, respectively. Similarly, the proportion of energy intake from carbohydrate declined at midmorning and late evening in boys, and at midmorning and late evening in girls, respectively. There was an increase in the proportion of energy from carbohydrate at breakfast in girls, and the proportion of energy from fat at mid-morning. Similarly, in boys, there was an increase in proportion of energy intake from fat at midmorning and an increase in proportion of energy intake from carbohydrate at lunch.

The type of eating occasion (main meal vs. snack) was a significant predictor of the macronutrient composition, such that the average composition of between-meal eating occasions was higher in carbohydrate and lower in protein and fat than the average composition of main meals. These findings were similar across both years and in both boys and girls (see supplementary material).

\section{Sensitivity analysis}

Sensitivity analyses were conducted including only individuals with accurate reporting of energy intake (boys $n=1583$, girls $n=1778$ ). Excluding under-reporters and over-reporters did not affect the rate of change (slope) in proportion of energy intake at different eating occasions, with the exception of dinner in girls wherein the rate of decline in proportion of energy intake was greater compared to previous models. In relation to the intercept, mean proportion of energy intake at age 10 was found to be higher at dinner and extras and lower at late evening for both boys and girls compared to previous models. At individual level, the random effects were also affected such that there were differences in the SD of the slope. These results are presented as supplementary material.

\section{Discussion}

To our knowledge this is the first study to describe changes in the distribution of energy and macronutrient composition of eating occasions in a cohort of boys and girls growing up in the United Kingdom during their transition from childhood to early adolescence. Lunch and dinner constituted the most important eating occasions, with the greatest contributions to energy intake. Breakfast contributed approximately $15 \%$ of total daily energy intake while lunch and dinner combined contributed around $60 \%$. Overall, the contribution of lunch and dinner to energy intake seen in this study is consistent with previous cohort studies in the United States, the Netherlands and France (deCastro, Bellisle, Feunekes, Dalx \& DeGraaf, 1997).

One of the main findings of the current study is the observed shift in time-of-day of energy and macronutrient intake for both sexes, with greater proportions of intake between meals (midmorning, late evening, extras) and lower intakes at main meals (breakfast, dinner) at age 13 years compared to 10 years. The contribution of eating occasions between the main meals was almost double the contribution of breakfast to energy intake and increased between 10 and 13 years by about $7 \%$ of energy. Consistent with these findings, we observed a rise in the proportion of consumers in both the mid-morning period in both boys and girls, and late evening period in girls. These changes in time-of-day of energy intake are likely to be a reflection of age-related changes in eating behavior, although it is not possible to distinguish them from time trends given the design of this study. For instance, the findings are in agreement with the general trends in Nordic countries characterised by increased meal skipping and reduced regularity of main meals (Samuelson, 2000). Similarly, increases in snacking behavior between 1989-91 and 1994-98 and between 199498 and 2003-06 have been documented crosssectionally in US children, with snacks contributing to $27 \%$ of children's total daily energy intake (Piernas \& Popkin, 2010b). This rise in the contribution of snacking to total daily energy intake has also been observed in US adults, where snacks contribute $24 \%$ of total daily energy intake in 2006 compared to $18 \%$ in 1977 (Piernas \& Popkin, 2010a). In adults, this rise was due to an increase in the number of people reporting consuming snacks from $71 \%$ to $97 \%$ (Piernas \& Popkin, 2010a).

Regardless as to whether our findings are due to age or time trends, the above results are concerning since snacking typically occurs outside the home and family meals. Adolescents who snack frequently on the run or during leisure time are more likely to skip meals (Savige, Macfarlane, Ball, Worsley \& Crawford, 2007). This can carry multiple health implications since regular family meals during early adolescence are known to be associated with the formation of healthy eating 
habits in adulthood that include higher intakes of fruit and vegetables, less breakfast skipping especially in girls, more frequent dinner meals and greater priority to meal structure (Larson, Fulkerson, Story \& Neumark-Sztainer, 2012).

In the present study, the average composition of between meals eating occasions was found to be higher in carbohydrate and lower in protein and fat than the average composition of main meals. This could be a point of concern if the main carbohydrate type was simple sugars, as regular between meal consumption of sugar-sweetened beverages has been shown to increase risk of overweight amongst preschool-aged children (Dubois, Farmer, Girard \& Peterson, 2007). In ALSPAC, consumption of sugar-sweetened beverages has increased between ages five and seven years from $57 \mathrm{~g} / \mathrm{d}$ to $67 \mathrm{~g} / \mathrm{d}$ (Johnson et al., 2007). In National Diet and Nutrition Survey (NDNS) rolling programme, consumption of sugarsweetened beverages was found to double from ages four-10 years to 11-18 years (Whitton et al., 2011). Together these findings may point towards between meal eating occasions as being important target points for future policies and dietary recommendation around healthy eating. However, further analyses are needed to examine type and sources of macronutrients consumed between meals in the ALSPAC cohort.

The decline in the proportion of daily energy intake from breakfast in both boys and girls and the rise in the proportion of daily energy intake from late evening meals in girls are also a matter of concern as breakfast skipping and eating later in the day are known risk factors for the development of chronic diseases and obesity. Overweight and obese children often report eating less at breakfast and more at dinner than their leaner counterparts (Bellisle et al., 1988). Eating breakfast is also frequently associated with a better diet quality, higher energy intake but lower body weight compared to breakfast skipping which is related to lower energy intake but higher BMI (Rampersaud et al., 2005). More recent evidence suggests that this unequivocal association between breakfast skipping, lower daily energy intake and higher BMI could be due to breakfast skipping being related to lower physical activity in adolescent girls (Corder et al., 2011). It is noteworthy that the prevalence of breakfast skipping in the current cohort is lower than that reported in US children, which averages
$20 \%$ of children (Deshmukh-Taskar et al., 2010). Nonetheless, the increasing trend in breakfast skipping might constitute a risk for obesity, particularly when considering current evidence that demonstrates that an irregular pattern of meals produces lower postprandial energy expenditure compared with regular meal frequency (Farshchi, Taylor \& Macdonald, 2004, 2005a). In relation to eating later in the day, recent evidence suggests that two-thirds of US children consume an evening snack (Nicklas, Baranowski, Cullen \& Berenmson, 2001). Similarly, we have previously demonstrated a trend towards a shift in energy intake towards later in the day in adults over the course of two decades in the 1946 British Birth Cohort (Almoosawi, Winter, Prynne, Hardy \& Stephen, 2012). Adults who reported having higher energy intake late in the evening had a greater rise in systolic and diastolic blood pressure between ages 43 and 53 years (Almoosawi et al., 2013b). Several explanations could be provided for the detrimental effects of eating late in the day. For instance, eating later in the day has a lower impact on satiety, resulting in higher intake of energy over the day (deCastro, 2007). Similarly insulin sensitivity declines progressively through the day. Thus, consumption of a standard meal in the evening produces greater postprandial glucose and insulin responses, an effect that is carried over to subsequent breakfast (Sato et al., 2011). Based on this evidence, it will be imperative to study the impact of skipping breakfast and eating later in the day on BMI trajectories in the ALSPAC cohort. Moreover, further research is required to identify children with an irregular meal pattern and study the relationship between such eating pattern and BMI.

In the current study, there was a reduction in the percentage of energy derived from fat at breakfast and lunch. The contribution of fat to total daily energy intake also declined between ages 10 and 13 years, in accordance with the current nutritional guidelines to reduce fat intake to $35 \%$ of total energy intake. Although differentiating between age- and time-effects is difficult in a birth cohort, it is likely that the observed changes in macronutrient composition reflect time-effects and changes in parents' or carer's food choices as a result of dietary recommendations and nutrition education campaigns. To emphasise, in the National Diet and Nutrition Survey (NDNS) rolling programme, 
consumption of semi-skimmed milk has replaced consumption of whole milk in both children and adults (Whitton et al., 2011). There has also been a small reduction in the consumption of savoury snacks and chips in children, and an increase in consumption of reduced fat spreads (Whitton et al., 2011). In adults in National Survey of Health and Development (NSHD), the reduction in percentage of energy derived from fat has been attributed to a reduction in fat content of meat and meat products arising from improvements in butchery methods, animal feeds, and selective breeding (Prynne, Paul, Mishra, Greenberg \& Wadsworth, 2005). Generally in the US and the UK, children's diets have improved as evident by the reduction in the consumption of fats/oils, breads/grains, red meat, chocolate confectionery, candy, and eggs, and increased quantities of fruit/fruit juices, beverages, and poultry (Nicklas et al., 2001; Whitton et al., 2011). However, it has been hypothesized that changes in specific eating patterns, such as increased frequency of meals eaten outside home, portion size, snacking and meal-skipping, may underlie the rise in obesity prevalence among children (Nicklas et al., 2001). This emphasises the need for research to investigate other aspects of eating behaviours such as meal frequency, composition, regularity and diurnal rhythms in energy and macronutrient distribution in relation to health.

The composition of breakfast and its relation to health has received growing attention in the past decades in relation to weight control (DeshmukhTaskar et al., 2012; Deshmukh-Taskar et al., 2010) and cognitive function (Mahoney et al., 2005). In the Third National Health and Nutrition Examination Survey, Cho and colleagues reported that subjects who ate ready-to-eat cereals had significantly lower BMI compared to breakfast skippers and meat and egg eaters, while those who reported fruit or vegetable consumption had significantly lower daily energy intakes (Cho et al., 2003). Similar findings have been observed in other studies (Deshmukh-Taskar et al., 2012; DeshmukhTaskar et al., 2010). Thus, the implications of the observed changes in energy and macronutrient distribution trends in ALSPAC, and of the observed sex-differences in trends, remain to be elucidated, particularly in relation to overweight and obesity. Circadian rhythms are central to the regulation of physiological and behavioural processes in humans, and disturbances in circadian rhythms have been reported to be associated with numerous chronic disease (Huang, Ramsey, Marcheva \& Bass, 2011; Lowden, Moreno, Holmback Lennernas \& Tucker, 2010; Scheer, Hilton, Mantzoros \& Shea, 2009). As a consequence, further interventional and epidemiological research is required to understand the implications of our findings, and assess their association with long-term health outcomes and weight gain. Likewise, factors determining the timeof-day and nutrient composition of eating occasions and the impact of the context of eating need to be elucidated. In future, it will also be interesting to investigate the energy and nutrient density of eating occasion in attempt to examine whether consumption of meals higher in energy density later in the day combined with lower physical activity is associated with early biomarkers of cardiovascular disease and weight gain.

The strengths of the current analyses lies in the availability of dietary data over two time-points which permitted the examination of changes in energy and macronutrient distribution during the transition from childhood to adolescence in the same individuals, large sample size, and robustness of the dietary assessment method. Weaknesses include use of pre-defined eating occasions, which did no permit investigating changes in the frequency and number of eating occasions. The inclusion of an "extras" eating occasion also poses a strong limitation as children who failed to remember the eating occasion at which they consumed a certain food or drink may have opted to report the missed item within the extras eating occasion, thereby accounting for the change in the proportion of consumers between ages 10 and 13 years. We also did not investigate patterns of sleeping which may determine the time-of-day of eating. Furthermore, children in ALSPAC have been recruited from one prescribed area of the UK; hence the sample might not be representative of the entire population. Finally, the most significant limitation of the current study is the missing data as not all children provided data on diet, BMI or potential confounders. This may limit the generalisability of the current findings and suggests a need for further studies using other cohort samples.

In conclusion, breakfast and to a greater extent lunch and dinner contributed the greatest proportion of energy and macronutrient intake in 
both girls and boys at both age 10 and 13 years. However, the contribution of breakfast and dinner to total daily energy intake declined between ages 10 and 13 years, with a switch towards greater energy consumption at mid-morning and late evening. Further studies are required to assess the implications of these findings. Further experimental studies are also required to examine the impact of manipulating time-of-day and nutrient composition of eating occasions on health.

\section{Acknowledgements}

We are extremely grateful to all the families who took part in this study, the midwives for their help in recruiting them and the whole ALSPAC team, which includes interviewers, computer and laboratory technicians, clerical workers, research scientists, volunteers, managers, receptionists and nurses. The UK Medical Research Council and the Wellcome Trust (grant ref 102215/2/13/2) and the University of Bristol provide core support for ALSPAC. This analysis was funded by the UK National Prevention Research Initiative (strategic grant G0701939).

\section{References}

Almoosawi, S., Prynne, C. J., Hardy, R., \& Stephen, A. M. (2012). Time-of-day and nutrient composition of eating occasions: prospective association with the metabolic syndrome in the 1946 British birth cohort. International Journal of Obesity (Lond), 37(5), 725-31.

http://dx.doi.org/10.1038/ijo.2012.103

Almoosawi, S., Prynne, C. J., Hardy, R., \& Stephen, A. M. (2013a). Diurnal eating rhythms: Association with long-term development of diabetes in the 1946 British birth cohort. Nutrition Metabolism and Cardiovascular Diseases, In Press. http://dx.doi.org/10.1016/j.numecd.2013.01.003

Almoosawi, S., Prynne, C. J., Hardy, R., \& Stephen, A. M. (2013b). Time-of-day of energy intake: association with hypertension and blood pressure 10 years later in the 1946 British Birth Cohort. Journal of Hypertension, 31(5), 882-92. http://dx.doi.org/10.1097/HJH.0b013e32835ecc06

Almoosawi, S., Winter, J., Prynne, C. J., Hardy, R., \& Stephen, A. M. (2012). Daily profiles of energy and nutrient intakes: are eating profiles changing over time? European Journal of Clinical Nutrition, 66(6), 678-686. http://dx.doi.org/10.1038/ejcn.2011.210

Bellisle, F., Rolland-Cachera, M. F., Deheeger, M., \& Guilloud-Bataille, M. (1988). Obesity and food intake in children: evidence for a role of metabolic and/or behavioral daily rhythms. Appetite, 11(2), 111-118. http://dx.doi.org/10.1016/S0195-6663(88)80010-2

Bray, M. S., Tsai, J. Y., Villegas-Montoya, C., Boland, B. B., Blasier, Z., Egbejimi, O., Kueht, M., \& Young, M. E., (2010). Time-of-day-dependent dietary fat consumption influences multiple cardiometabolic syndrome parameters in mice. International Journal of Obesity (Lond), 34(11), 1589-1598. http://dx.doi.org/10.1038/ijo.2010.63

Chan, W., Brown, J., \& Buss, D. (1994). Miscellaneous Foods. Fourth supplement to 5th Edition of McCance \& Widdowson's The Composition of Foods. Cambridge: The Royal Soceity of Chemsitry. http://dx.doi.org/10.1039/9781849732604

Chane, W., Brown, J., Lee, S., \& Buss, D. (1995). Meat, Poultry and Game. Fifth supplement to 5th Edition of McCance \& Widdowson's The Composition of Foods. Cambridge: The Royal Society of Cambridge. http://dx.doi.org/10.1039/9781849732475

Cho, S., Dietrich, M., Brown, C. J., Clark, C. A., \& Block, G. (2003). The effect of breakfast type on total daily energy intake and body mass index: results from the Third National Health and Nutrition Examination Survey (NHANES III). Journal of the American College of Nutrition, 22(4), 296-302. http://dx.doi.org/10.1080/07315724.2003.10719307

Cole, T. J., Bellizzi, M. C., Flegal, K. M., \& Dietz, W. H. (2000). Establishing a standard definition for child overweight and obesity worldwide: international survey. BMJ, 320(7244), 1240-1243. http://dx.doi.org/10.1136/bmj.320.7244.1240 
Cole, T. J., Flegal, K. M., Nicholls, D., \& Jackson, A. A. (2007). Body mass index cut offs to define thinness in children and adolescents: international survey. BMJ, 335(7612), 194. http://dx.doi.org/10.1136/bmj.39238.399444.55

Corder, K., van Sluijs, E. M. F., Steele, R. M., Stephen, A. M., Dunn, V., Bamber, D., Goodyer, I., Griffin, S. J., \& Ekelund, U. (2011). Breakfast consumption and physical activity in British adolescents. British Journal of Nutrition, 105(2), 316-321. http://dx.doi.org/10.1017/S0007114510003272

deCastro, J. M. (2007). The time of day and the proportions of macronutrients eaten are related to total daily food intake. British Journal of Nutrition, 98(5), 1077-1083.

deCastro, J. M., Bellisle, F., Feunekes, G. I. J., Dalix, A. M., \& DeGraaf, C. (1997). Culture and meal patterns: A comparison of the food intake of free-living American, Dutch, and French students. Nutrition Research, 17(5), 807-829. http://dx.doi.org/10.1016/S0271-5317(97)00050-X

Deshmukh-Taskar, P., Nicklas, T. A., Radcliffe, J. D., O'Neil, C. E., \& Liu, Y. (2012). The relationship of breakfast skipping and type of breakfast consumed with overweight/obesity, abdominal obesity, other cardiometabolic risk factors and the metabolic syndrome in young adults. The National Health and Nutrition Examination Survey (NHANES): 1999-2006. Public Health Nutrition, 1-10.

Deshmukh-Taskar, P. R., Nicklas, T. A., O'Neil, C. E., Keast, D. R., Radcliffe, J. D., \& Cho, S. (2010). The relationship of breakfast skipping and type of breakfast consumption with nutrient intake and weight status in children and adolescents: the National Health and Nutrition Examination Survey 1999-2006. Journal of the American Dietic Association, 110(6), 869-878. http://dx.doi.org/10.1016/j.jada.2010.03.023

Dubois, L., Farmer, A., Girard, M., \& Peterson, K. (2007). Regular sugar-sweetened beverage consumption between meals increases risk of overweight among preschool-aged children. Journal of the American Dietic Association, 107(6), 924-934; discussion 934-925. http://dx.doi.org/10.1016/j.jada.2007.03.004

Emmett, P. (2009). Dietary assessment in the Avon Longitudinal Study of Parents and Children. European Journal Clinical Nutrition, 63 Supp/ 1, S38-44. http://dx.doi.org/10.1038/ejcn.2008.63

Farshchi, H. R., Taylor, M. A., \& Macdonald, I. A., (2004). Regular meal frequency creates more appropriate insulin sensitivity and lipid profiles compared with irregular meal frequency in healthy lean women. European Journal of Clinical Nutrition, 58(7), 1071-1077. http://dx.doi.org/10.1038/sj.ejcn.1601935

Farshchi, H. R., Taylor, M. A., \& Macdonald, I. A. (2005a). Beneficial metabolic effects of regular meal frequency on dietary thermogenesis, insulin sensitivity, and fasting lipid profiles in healthy obese women. American Journal of Clinical Nutrition, 81(1), 16-24.

Farshchi, H. R., Taylor, M. A., \& Macdonald, I. A. (2005b). Deleterious effects of omitting breakfast on insulin sensitivity and fasting lipid profiles in healthy lean women. American Journal of Clinical Nutrition, 81(2), 388-396.

Gaina, A., Sekine, M., Chandola, T., Marmot, M., \& Kagamimori, S. (2009). Mother employment status and nutritional patterns in Japanese junior high schoolchildren. International Journal of Obesity, 33(7), 753-757. http://dx.doi.org/10.1038/ijo.2009.103

Boyd, A., Golding, J., Macleod, J., Lawlor, D. A., Fraser, A., Henderson, J., Molloy, L., Ness, A., Ring, S., \& Davey Smith G. (2013). Cohort profile: The Children of the 90s - the index offspring of the Avon Longitudinal Study of Parents and Children. International Journal of Epidemiology, 42(1), 111-27. Gregory, J. R., Collins, D. L., Davies, P. S. W., Hughes, J. M., \& Clarke, P. C. (1995). The Diet and Nutrition Survey: children aged 1.5-4.5 years (Vol. 1 Report of the diet and nutrition survey). London: The Stationary Office.

Gregory, J. R., \& Lowe, S. (2000). National Diet and Nutrition Survey: young people aged 4-18 years (Vol. 1 Report of the diet and nutrition survey.). London: The Statitionary Office.

Hallstrom, L., Labayen, I., Ruiz, J. R., Patterson, E., Vereecken, C. A., Breidenassel, C., Gottrand, F., Huybrechts, I., Manios, Y., Mistura, L., Widhalm, K., Kondaki, K., Moreno, L. A., \& Sjostrom, M. (2012). Breakfast consumption and CVD risk factors in European adolescents: the HELENA (Healthy Lifestyle in Europe by Nutrition in Adolescence) Study. Public Health Nutrition, 1-10. 
Holland, B., Unwin, I., \& Buss, D. (1991). Vegetables, Herbs and Spices. Fifth supplement to 4th Edition of McCance \& Widdowson's The Composition of Foods. Cambridge: The Royal Society of Chemistry. http://dx.doi.org/10.1039/9781849732499

Holland, B., Unwin, I., \& Buss, D. . (1988). Cereals and Cereal Products. Third supplement to 4th Edition of McCance \& Widdowson's The Composition of Foods. . Cambridge: The Royal Society of Chemistry.

Holland, B., Unwin, I., \& D., Buss. (1989). Milk Products and Eggs. Fourth supplement to 4th Edition of McCance \& Widdowson's The Composition of Foods. Cambridge: The Royal Society of Chemistry.

Holland, B., Welch, A., Unwin, I., Buss, D., Paul, A. , \& Southgate, D. (1991). McCance \&Widdowson's The Composition of Foods, 5th Edition. Cambridge: The Royal Society of Chemistry.

Holland, B., Welsh, A., \& Buss, D. (1992a). Fruits and Nuts. First supplement to 5th Edition of McCance \& Widdowson's The Composition of Foods. Cambridge: The Royal Society of Chemsitry. http://dx.doi.org/10.1039/9781849732482

Holland, B., Welsh, A., \& Buss, D. (1992b). Vegetable Dishes. Second supplement to 5th Edition of McCance \& Widdowson's The Composition of Foods. Cambridge: The Royal Society of Chemistry.

Holland, D., Brown, J., \& Buss, D. (1993). Fish and Fish Products. Third supplement to 5th Edition of McCance \& Widdowson's The Composition of Foods. Cambridge: The Royal Society of Chemistry. http://dx.doi.org/10.1039/9781849732611

Huang, W., Ramsey, K. M., Marcheva, B., \& Bass, J. (2011). Circadian rhythms, sleep, and metabolism. Journal of Clinical Investigation, 121(6), 2133-2141. http://dx.doi.org/10.1172/JCl46043

Johnson, L., Mander, A. P., Jones, L. R., Emmett, P. M., \& Jebb, S. A. (2007). Is sugar-sweetened beverage consumption associated with increased fatness in children? Nutrition, 23(7-8), 557-563. http://dx.doi.org/10.1016/j.nut.2007.05.005

Johnson, L., Mander, A. P., Jones, L. R., Emmett, P. M., \& Jebb, S. A. (2008). A prospective analysis of dietary energy density at age 5 and 7 years and fatness at 9 years among UK children. Int J Obes (Lond), 32(4), 586-593. http://dx.doi.org/10.1038/sj.ijo.0803746

Keski-Rahkonen, A., Kaprio, J., Rissanen, A., Virkkunen, M., \& Rose, R. J. (2003). Breakfast skipping and health-compromising behaviors in adolescents and adults. European Journal of Clinical Nutrition, 57(7), 842-853. http://dx.doi.org/10.1038/sj.ejcn.1601618

Larson, N., Fulkerson, J., Story, M., \& Neumark-Sztainer, D. (2012). Shared meals among young adults are associated with better diet quality and predicted by family meal patterns during adolescence. Public Health Nutrition, 1-11.

Lowden, A., Moreno, C., Holmback, U., Lennernas, M., \& Tucker, P. (2010). Eating and shift work - effects on habits, metabolism and performance. Scandinavian Journal of Work, Environment \& Health, 36(2), 150-162. http://dx.doi.org/10.5271/sjweh.2898

Mahoney, C. R., Taylor, H. A., Kanarek, R. B., \& Samuel, P. (2005). Effect of breakfast composition on cognitive processes in elementary school children. Physiology \& Behavior, 85(5), 635-645. http://dx.doi.org/10.1016/j.physbeh.2005.06.023

Mannino, M. L., Lee, Y., Mitchell, D. C., Smiciklas-Wright, H., \& Birch, L. L. (2004). The quality of girls' diets declines and tracks across middle childhood. International Journal of Behavioral Nutrition and Physical Activity, 1(1), 5. http://dx.doi.org/10.1186/1479-5868-1-5

Nicklas, T. A., Baranowski, T., Cullen, K. W., \& Berenson, G. (2001). Eating patterns, dietary quality and obesity. Journal of the American College of Nutrition, 20(6), 599-608. http://dx.doi.org/10.1080/07315724.2001.10719064

Piernas, C., \& Popkin, B. M. (2010a). Snacking increased among U.S. adults between 1977 and 2006. J Nutrition, 140(2), 325-332. http://dx.doi.org/10.3945/jn.109.112763

Piernas, C., \& Popkin, B. M. (2010b). Trends in snacking among U.S. children. Health Affairs (Millwood), 29(3), 398-404. http://dx.doi.org/10.1377/hlthaff.2009.0666

Poppitt, S. D., Swann, D., Black, A. E., \& Prentice, A. M. (1998). Assessment of selective under-reporting of food intake by both obese and non-obese women in a metabolic facility. International journal of obesity and related metabolic disorders : journal of the International Association for the Study of Obesity, 22(4), 303-311. http://dx.doi.org/10.1038/sj.ijo.0800584 
Prynne, C. J., Paul, A. A., Mishra, G. D., Greenberg, D. C., \& Wadsworth, M. E. (2005). Changes in intake of key nutrients over 17 years during adult life of a British birth cohort. British Journal of Nutrition, 94(3), 368-376. http://dx.doi.org/10.1079/BJN20041404

Rampersaud, G. C., Pereira, M. A., Girard, B. L., Adams, J., \& Metzl, J. D. (2005). Breakfast habits, nutritional status, body weight, and academic performance in children and adolescents. Journal of the American Dietic Association, 105(5), 743-760; quiz 761-742. http://dx.doi.org/10.1016/j.jada.2005.02.007

Rennie, K. L., Coward, A., \& Jebb, S. A. (2007). Estimating under-reporting of energy intake in dietary surveys using an individualised method. British Journal of Nutrition, 97(6), 1169-1176. http://dx.doi.org/10.1017/S0007114507433086

Samuelson, G. (2000). Dietary habits and nutritional status in adolescents over Europe. An overview of current studies in the Nordic countries. European Journal of Clinical Nutrition, 54 Suppl 1, S21-28. http://dx.doi.org/10.1038/sj.ejcn.1600980

Sato, M., Nakamura, K., Ogata, H., Miyashita, A., Nagasaka, S., Omi, N., Yamaguchi, S., Hibi, M., Umeda, T., Nakaji, S., \& Tokuyama, K. (2011). Acute effect of late evening meal on diurnal variation of blood glucose and energy metabolism. Obesity Research \& Clinical Practice, 5(3), E220-E228. http://dx.doi.org/10.1016/j.orcp.2011.02.001

Savige, G., Macfarlane, A., Ball, K., Worsley, A., \& Crawford, D. (2007). Snacking behaviours of adolescents and their association with skipping meals. International Journal of Behavioral Nutrition and Physical Activity, 4, 36. http://dx.doi.org/10.1186/1479-5868-4-36

Scheer, F. A., Hilton, M. F., Mantzoros, C. S., \& Shea, S. A. (2009). Adverse metabolic and cardiovascular consequences of circadian misalignment. Proceedings of the National Academy of Sciences U S A, 106(11), 4453-4458. http://dx.doi.org/10.1073/pnas.0808180106

Sierra-Johnson, J., Unden, A. L., Linestrand, M., Rosell, M., Sjogren, P., Kolak, M., De Faire, U., Fisher, R. M., \& Hellenius, M. L. (2008). Eating meals irregularly: a novel environmental risk factor for the metabolic syndrome. Obesity (Silver Spring), 16(6), 1302-1307. http://dx.doi.org/10.1038/oby.2008.203

te Velde, S. J., Twisk, J. W., \& Brug, J. (2007). Tracking of fruit and vegetable consumption from adolescence into adulthood and its longitudinal association with overweight. British Journal of Nutrition, 98(2), 431-438. http://dx.doi.org/10.1017/S0007114507721451

Whitton, C., Nicholson, S. K., Roberts, C., Prynne, C. J., Pot, G. K., Olson, A., Fitt, E., Cole, D., Teucher, B., Bates, B., Henderson, H., Pigott, S., Deverill, C., Swan, G., \& Stephen, A. M. (2011). National Diet and Nutrition Survey: UK food consumption and nutrient intakes from the first year of the rolling programme and comparisons with previous surveys. British Journal of Nutrition, 106(12), 1899-1914. http://dx.doi.org/10.1017/S0007114511002340

Wrieden, W. L., Longbottom, P. J., Adamson, A. J., Ogston, S. A., Payne, A., Haleem, M. A., \& Barton, K. L. (2008). Estimation of typical food portion sizes for children of different ages in Great Britain. Britush Journal of Nutrition, 99(6), 1344-1353. http://dx.doi.org/10.1017/s0007114507868516 
Table 1. Unadjusted energy and macronutrient intake at different eating occasions in boys and girls aged 10 and 13 years in ALSPAC. Data includes nonconsumers.

oys

Age $13(n=1561) \quad$ Age $10(n=1759) \quad$ Girls $\quad 13(n=1759)$

Age $\mathbf{1 0}(\mathbf{n}=\mathbf{1 5 6 1})$
Age $\mathbf{1 3}(\mathrm{n}=\mathbf{1 5 6 1})$

\begin{tabular}{|c|c|c|c|c|c|c|c|c|c|}
\hline & & Adsolute mike & medn (95\% (l) & AUsulute mitake & Mean (95\% (l) & ADsulute miake & mednl (9כ\% (I) & ADsulute mike & Medn (9כ\% (1) \\
\hline & & $\mathrm{g}$ & $\%$ & $\mathrm{~g}$ & $\%$ & $\mathrm{~g}$ & $\%$ & $\mathrm{~g}$ & $\%$ \\
\hline \multirow[t]{4}{*}{ Breakfast } & Energy & 327 & $16.6(16.3,16.9)$ & 317 & $14.7(14.4,15.1)$ & 280 & $15.8(15.5,16.1)$ & 235 & $13.3(12.9,13.6)$ \\
\hline & Carbohydrate & 53 & $20.1(19.8,20.5)$ & 52 & $18(17.5,18.4)$ & 45 & $19(18.7,19.4)$ & 39 & $16.3(15.9,16.8)$ \\
\hline & Protein & 10 & $15.8(15.5,16.1)$ & 11 & $13.8(13.4,14.2)$ & 9 & $14.9(14.5,15.2)$ & 8 & $12(11.7,12.4)$ \\
\hline & Fat & 10 & $12(11.7,12.4)$ & 9 & $10.5(10.1,10.9)$ & 9 & $11.7(11.4,12.1)$ & 7 & $9.4(9,9.7)$ \\
\hline \multirow[t]{4}{*}{ Mid-morning } & Energy & 96 & $4.9(4.6,5.1)$ & 170 & $7.8(7.5,8.2)$ & 99 & $5.6(5.3,5.8)$ & 147 & $8.3(8,8.6)$ \\
\hline & Carbohydrate & 14 & $5.3(5.1,5.6)$ & 24 & $8.5(8.1,8.8)$ & 14 & $6.1(5.8,6.4)$ & 21 & $9(8.7,9.4)$ \\
\hline & Protein & 2 & $3(2.8,3.2)$ & 4 & $5.6(5.3,5.9)$ & 2 & $3.4(3.2,3.6)$ & 4 & $5.8(5.5,6.1)$ \\
\hline & Fat & 4 & $4.9(4.7,5.2)$ & 7 & $7.9(7.5,8.3)$ & 4 & $5.6(5.3,5.9)$ & 6 & $8.3(7.9,8.7)$ \\
\hline \multirow[t]{4}{*}{ Lunch } & Energy & 580 & $29.7(29.4,30.1)$ & 591 & $27.6(27.2,28.1)$ & 544 & $31(30.6,31.3)$ & 499 & $28.3(27.8,28.7)$ \\
\hline & Carbohydrate & 72 & $27.7(27.4,28.1)$ & 75 & $26.2(25.8,26.7)$ & 68 & $29.1(28.7,29.4)$ & 63 & $26.8(26.4,27.3)$ \\
\hline & Protein & 19 & $28.9(28.5,29.4)$ & 21 & $26.7(26.2,27.2)$ & 18 & $30.2(29.7,30.6)$ & 17 & $27.4(26.9,27.9)$ \\
\hline & Fat & 26 & $33(32.5,33.5)$ & 25 & $30.1(29.5,30.6)$ & 24 & $34(33.5,34.5)$ & 22 & $30.6(30.1,31.2)$ \\
\hline \multirow[t]{4}{*}{ Mid-afternoon } & Energy & 178 & $9(8.6,9.3)$ & 159 & $7.2(6.9,7.6)$ & 167 & $9.4(9,9.7)$ & 138 & $7.7(7.3,8.2)$ \\
\hline & Carbohydrate & 26 & $9.6(9.3,10)$ & 22 & $7.5(7.2,7.9)$ & 24 & $9.9(9.6,10.3)$ & 19 & $7.9(7.5,8.3)$ \\
\hline & Protein & 4 & $6(5.6,6.4)$ & 4 & $5.7(5.3,6.1)$ & 4 & $6.9(6.5,7.3)$ & 4 & $6.5(6,6.9)$ \\
\hline & Fat & 7 & $9.2(8.8,9.6)$ & 6 & $7.4(7,7.8)$ & 7 & $9.5(9.1,9.9)$ & 6 & $8.1(7.6,8.5)$ \\
\hline \multirow[t]{4}{*}{ Dinner } & Energy & 601 & $30.7(30.2,31.1)$ & 596 & $28(27.4,28.6)$ & 528 & $29.8(29.4,30.3)$ & 493 & $28.1(27.6,28.7)$ \\
\hline & Carbohydrate & 73 & $27.6(27.2,28.1)$ & 71 & $24.9(24.3,25.4)$ & 64 & $27.1(26.6,27.5)$ & 59 & $25.1(24.6,25.7)$ \\
\hline & Protein & 25 & $38.2(37.6,38.8)$ & 27 & $34.9(34.2,35.7)$ & 22 & $37.1(36.5,37.7)$ & 22 & $35.4(34.7,36.2)$ \\
\hline & Fat & 25 & $32(31.5,32.6)$ & 25 & $29.7(29,30.4)$ & 22 & $31(30.4,31.5)$ & 20 & $29.4(28.7,30)$ \\
\hline \multirow[t]{4}{*}{ Late evening } & Energy & 158 & $7.9(7.5,8.2)$ & 239 & $10.9(10.4,11.4)$ & 134 & $7.4(7,7.7)$ & 188 & $10.4(10,10.9)$ \\
\hline & Carbohydrate & 22 & $8(7.7,8.4)$ & 31 & $10.6(10.1,11.1)$ & 18 & $7.5(7.2,7.8)$ & 24 & $10.2(9.7,10.6)$ \\
\hline & Protein & 5 & $7.5(7.1,7.9)$ & 9 & $11.5(10.9,12.1)$ & 4 & $7.1(6.7,7.5)$ & 7 & $11(10.5,11.6)$ \\
\hline & Fat & 6 & $7.7(7.3,8.1)$ & 10 & $11.1(10.5,11.7)$ & 5 & $7.2(6.9,7.6)$ & 8 & $10.5(10,11.1)$ \\
\hline \multirow[t]{4}{*}{ Extras } & Energy & 25 & $1.3(1.1,1.4)$ & 82 & $3.6(3.4,3.9)$ & 19 & $1.1(0.9,1.2)$ & 71 & $3.9(3.6,4.2)$ \\
\hline & Carbohydrate & 4 & $1.5(1.4,1.7)$ & 13 & $4.3(4,4.7)$ & 3 & $1.3(1.1,1.5)$ & 11 & $4.6(4.3,4.9)$ \\
\hline & Protein & 0 & $0.5(0.5,0.6)$ & 1 & $1.7(1.6,1.9)$ & 0 & $0.5(0.4,0.5)$ & 1 & $1.8(1.7,2)$ \\
\hline & Fat & 1 & $1.1(1,1.3)$ & 3 & $3.4(3.1,3.7)$ & 1 & $0.9(0.8,1.1)$ & 3 & $3.7(3.4,4)$ \\
\hline \multirow[t]{4}{*}{ Day } & Energy & 1965 & - & 2152 & - & 1772 & - & 1771 & - \\
\hline & Carbohydrate & 264 & - & 288 & - & 237 & - & 236 & - \\
\hline & Protein & 67 & - & 77 & - & 59 & - & 63 & - \\
\hline & Fat & 79 & - & 85 & - & 72 & - & 71 & - \\
\hline
\end{tabular}

* Mean of $\%$ of daily intake 
Table 2. Unadjusted energy and macronutrient intake at different eating occasions in boys and girls aged 10 and 13 years in ALSPAC including only the consumers of each meal. ( $n$ shows the number of consumers within each eating occasion)

\begin{tabular}{|c|c|c|c|c|c|c|c|c|c|c|c|c|c|}
\hline & & \multicolumn{6}{|c|}{ Boys } & \multicolumn{6}{|c|}{ Girls } \\
\hline & & \multicolumn{3}{|c|}{ Age 10} & \multicolumn{3}{|c|}{ Age 13} & \multicolumn{3}{|c|}{ Age 10} & \multicolumn{3}{|c|}{ Age 13} \\
\hline & & \multicolumn{3}{|c|}{ Absolute } & \multicolumn{3}{|c|}{ Absolute } & \multicolumn{3}{|c|}{ Absolute } & \multicolumn{3}{|c|}{ Absolute } \\
\hline & & $\mathrm{N}$ & intake & mean* $(95 \% \mathrm{Cl})$ & $\mathrm{N}$ & intake & mean $(95 \% \mathrm{Cl})$ & $\mathrm{N}$ & intake & mean $(95 \% \mathrm{Cl})$ & $\mathrm{N}$ & intake & mean $(95 \% \mathrm{Cl})$ \\
\hline & & & $\mathrm{g}$ & $\%$ & & $\mathrm{~g}$ & $\%$ & & $\mathrm{~g}$ & $\%$ & & $\mathrm{~g}$ & $\%$ \\
\hline \multirow[t]{4}{*}{ Breakfast } & Energy & 1548 & 329.56 & $16.8(16.5,17.1)$ & 1509 & 327.92 & $15.2(14.9,15.6)$ & 1740 & 283.36 & $16(15.7,16.3)$ & 1638 & 251.96 & $14.2(13.9,14.6)$ \\
\hline & Carbohydrate & 1548 & 53.49 & $20.3(19.9,20.6)$ & 1509 & 53.45 & $18.6(18.2,19)$ & 1740 & 45.58 & $19.2(18.9,19.6)$ & 1638 & 41.4 & $17.5(17.1,17.9)$ \\
\hline & Protein & 1548 & 10.59 & $15.9(15.6,16.3)$ & 1509 & 11.01 & $14.3(13.9,14.7)$ & 1740 & 8.86 & $15(14.7,15.3)$ & 1638 & 8.12 & $12.9(12.6,13.3)$ \\
\hline & Fat & 1548 & 9.69 & $12.1(11.8,12.5)$ & 1509 & 9.33 & $10.9(10.5,11.3)$ & 1740 & 8.62 & $11.8(11.5,12.2)$ & 1638 & 7.18 & $10(9.7,10.4)$ \\
\hline \multirow[t]{4}{*}{ Mid-morning } & Energy & 1254 & 119.79 & $6.1(5.8,6.3)$ & 1313 & 201.63 & $9.3(9,9.7)$ & 1466 & 118.69 & $6.7(6.4,6.9)$ & 1552 & 166.31 & $9.4(9.1,9.7)$ \\
\hline & Carbohydrate & 1254 & 17.6 & $6.6(6.3,6.9)$ & 1313 & 29.02 & $10.1(9.7,10.4)$ & 1466 & 17.38 & $7.3(7,7.6)$ & 1552 & 24.1 & $10.2(9.9,10.6)$ \\
\hline & Protein & 1254 & 2.55 & $3.7(3.5,4)$ & 1313 & 5.21 & $6.7(6.3,7)$ & 1466 & 2.41 & $4.1(3.8,4.3)$ & 1552 & 4.06 & $6.5(6.2,6.9)$ \\
\hline & Fat & 1254 & 5.26 & $6.2(5.9,6.5)$ & 1313 & 8.33 & $9.4(9,9.8)$ & 1466 & 5.14 & $6.7(6.4,7)$ & 1552 & 6.83 & $9.4(9,9.8)$ \\
\hline \multirow[t]{4}{*}{ Lunch } & Energy & 1560 & 580 & $29.7(29.4,30.1)$ & 1554 & 593.35 & $27.8(27.3,28.2)$ & 1758 & 544.56 & $31(30.6,31.4)$ & 1748 & 502.61 & $28.4(28,28.9)$ \\
\hline & Carbohydrate & 1560 & 72.48 & $27.7(27.4,28.1)$ & 1554 & 74.86 & $26.3(25.9,26.8)$ & 1758 & 68.1 & $29.1(28.7,29.5)$ & 1748 & 63.22 & $27(26.6,27.4)$ \\
\hline & Protein & 1560 & 19.13 & $29(28.5,29.4)$ & 1554 & 20.64 & $26.8(26.3,27.3)$ & 1758 & 17.65 & $30.2(29.7,30.6)$ & 1748 & 17.26 & $27.6(27.1,28.1)$ \\
\hline & Fat & 1560 & 25.75 & $33(32.5,33.5)$ & 1554 & 25.62 & $30.2(29.6,30.8)$ & 1758 & 24.29 & $34(33.5,34.5)$ & 1748 & 21.83 & $30.8(30.3,31.4)$ \\
\hline \multirow[t]{4}{*}{ Mid-afternoon } & Energy & 1446 & 192.69 & $9.7(9.3,10)$ & 1206 & 205.27 & $9.4(8.9,9.8)$ & 1632 & 180.14 & $10.1(9.7,10.4)$ & 1318 & 184.49 & $10.3(9.9,10.8)$ \\
\hline & Carbohydrate & 1446 & 27.93 & $10.4(10.1,10.8)$ & 1206 & 28.77 & $9.8(9.4,10.2)$ & 1632 & 25.63 & $10.7(10.3,11)$ & 1318 & 25.12 & $10.6(10.1,11)$ \\
\hline & Protein & 1446 & 4.32 & $6.5(6.1,6.9)$ & 1206 & 5.81 & $7.4(6.9,7.9)$ & 1632 & 4.38 & $7.4(7,7.8)$ & 1318 & 5.42 & $8.6(8.1,9.2)$ \\
\hline & Fat & 1446 & 8.24 & $9.9(9.5,10.3)$ & 1206 & 8.74 & $9.6(9.1,10)$ & 1632 & 7.78 & $10.3(9.8,10.7)$ & 1318 & 7.96 & $10.8(10.2,11.3)$ \\
\hline \multirow[t]{4}{*}{ Dinner } & Energy & 1555 & 602.94 & $30.8(30.3,31.3)$ & 1523 & 610.43 & $28.7(28.1,29.2)$ & 1745 & 532.52 & $30.1(29.6,30.5)$ & 1716 & 505.47 & $28.8(28.3,29.4)$ \\
\hline & Carbohydrate & 1555 & 72.81 & $27.8(27.3,28.2)$ & 1523 & 72.41 & $25.5(25,26)$ & 1745 & 64.3 & $27.3(26.9,27.7)$ & 1716 & 60.2 & $25.8(25.3,26.3)$ \\
\hline & Protein & 1555 & 25.54 & $38.4(37.7,39)$ & 1523 & 27.51 & $35.8(35.1,36.5)$ & 1745 & 22.18 & $37.4(36.8,38)$ & 1716 & 22.86 & $36.3(35.6,37)$ \\
\hline & Fat & 1555 & 25.32 & $32.2(31.6,32.7)$ & 1523 & 25.52 & $30.4(29.8,31.1)$ & 1745 & 22.56 & $31.2(30.7,31.8)$ & 1716 & 20.98 & $30.1(29.5,30.8)$ \\
\hline \multirow[t]{4}{*}{ Late evening } & Energy & 1327 & 185.84 & $9.2(8.9,9.6)$ & 1325 & 281.43 & $12.9(12.3,13.4)$ & 1449 & 162.32 & $9(8.6,9.3)$ & 1497 & 220.89 & $12.3(11.8,12.8)$ \\
\hline & Carbohydrate & 1327 & 25.47 & $9.4(9.1,9.8)$ & 1325 & 36.63 & $12.5(12,13)$ & 1449 & 22.04 & $9.1(8.7,9.5)$ & 1497 & 28.74 & $12(11.5,12.4)$ \\
\hline & Protein & 1327 & 6.14 & $8.9(8.4,9.3)$ & 1325 & 10.8 & $13.6(12.9,14.3)$ & 1449 & 5.28 & $8.6(8.2,9.1)$ & 1497 & 8.36 & $13(12.3,13.6)$ \\
\hline & Fat & 1327 & 7.76 & $9.1(8.7,9.5)$ & 1325 & 11.64 & $13(12.4,13.7)$ & 1449 & 6.86 & $8.8(8.4,9.2)$ & 1497 & 9.28 & $12.4(11.8,12.9)$ \\
\hline \multirow[t]{4}{*}{ Extras } & Energy & 438 & 90.74 & $4.5(4.1,4.9)$ & 917 & 139.29 & $6.2(5.8,6.6)$ & 422 & 79.88 & $4.5(4,4.9)$ & 1150 & 108.6 & $6(5.6,6.3)$ \\
\hline & Carbohydrate & 438 & 14.88 & $5.5(5,5.9)$ & 917 & 22.48 & $7.4(6.9,7.8)$ & 422 & 13.21 & $5.4(4.9,6)$ & 1150 & 16.99 & $7(6.6,7.4)$ \\
\hline & Protein & 438 & 1.4 & $2(1.7,2.2)$ & 917 & 2.48 & $2.9(2.7,3.2)$ & 422 & 1.26 & $2(1.7,2.2)$ & 1150 & 1.98 & $2.8(2.6,3)$ \\
\hline & Fat & 438 & 3.98 & $4(3.6,4.5)$ & 917 & 6.08 & $5.7(5.3,6.2)$ & 422 & 3.7 & $3.9(3.4,4.4)$ & 1150 & 5.17 & $5.7(5.3,6.1)$ \\
\hline \multirow[t]{4}{*}{ Day } & Energy & 1561 & 1965.23 & - & 1561 & 2152.15 & - & 1759 & 1771.75 & - & 1759 & 1771.18 & - \\
\hline & Carbohydrate & 1561 & 263.83 & - & 1561 & 287.75 & - & 1759 & 236.48 & - & 1759 & 235.74 & - \\
\hline & Protein & 1561 & 66.51 & - & 1561 & 77.14 & - & 1759 & 58.95 & - & 1759 & 62.71 & - \\
\hline & Fat & 1561 & 78.95 & - & 1561 & 84.94 & - & 1759 & 72.22 & - & 1759 & 70.67 & - \\
\hline
\end{tabular}

- Mean of $\%$ of daily intake 
Figure 1. Percentage of consumers and non-consumers at any given eating occasion in boys and girls aged 10 and 13 years.

For every eating occasions, asterisk denotes significant differences in proportion of consumers between ages 10 and 13 years; ${ }^{*} \mathrm{P}<0.01 * * \mathrm{P}<0.001$
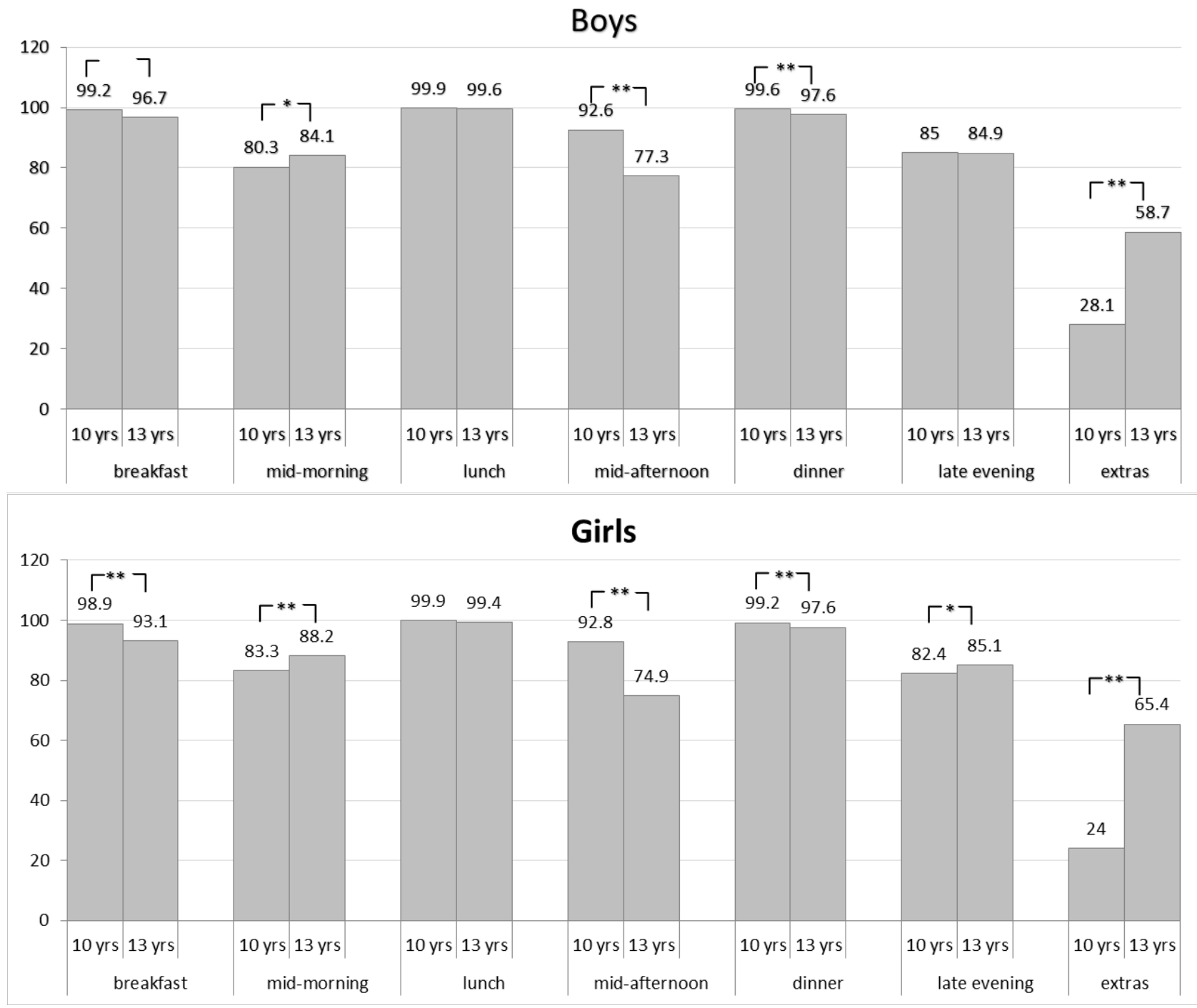
Table 3. Changes in energy intake and macronutrient composition of eating occasions in boy and girls between ages 10 and 13 years. Macronutrients expressed as proportion of energy intake.

\begin{tabular}{|c|c|c|c|c|c|c|c|c|c|c|c|c|c|c|}
\hline & & & \multicolumn{3}{|c|}{ Energy } & \multicolumn{3}{|c|}{ Carbohydrate (\% Energy) } & \multicolumn{3}{|c|}{ Protein (\% Energy) } & \multicolumn{3}{|c|}{ Fat (\% Energy) } \\
\hline & & & $\beta^{*}$ & $95 \% \mathrm{Cl}$ & P-value & $\boldsymbol{\beta}$ & $95 \% \mathrm{Cl}$ & P-value & $\beta$ & $95 \% \mathrm{Cl}$ & P-value & $\boldsymbol{\beta}$ & $95 \% \mathrm{Cl}$ & P-value \\
\hline \multirow[t]{14}{*}{ Boys $(n=3122)$} & Breakfast & Constant & 16.4 & $(15,17.9)$ & $<0.001$ & 61.6 & $(59.1,64.2)$ & $<0.001$ & 11.6 & $(10.8,12.4)$ & $<0.001$ & 26.8 & $(24.4,29.2)$ & $<0.001$ \\
\hline & & Age & -1.9 & $(-2.3,-1.5)$ & $<0.001$ & 0.1 & $(-0.7,0.8)$ & 0.824 & 0.5 & $(0.3,0.8)$ & $<0.001$ & -0.6 & $(-1.3,0.1)$ & 0.084 \\
\hline & Mid-morning & Constant & 6.5 & $(5.2,7.7)$ & $<0.001$ & 60.1 & $(56,64.1)$ & $<0.001$ & 6.2 & $(5,7.4)$ & $<0.001$ & 33.7 & $(29.9,37.6)$ & $<0.001$ \\
\hline & & Age & 3.1 & $(2.7,3.5)$ & $<0.001$ & -2.9 & $(-4.3,-1.5)$ & $<0.001$ & 1.8 & $(1.4,2.2)$ & $<0.001$ & 1.1 & $(-0.3,2.4)$ & 0.112 \\
\hline & Lunch & Constant & 28.2 & $(26.5,29.9)$ & $<0.001$ & 46.9 & $(45.2,48.7)$ & $<0.001$ & 12.6 & $(11.7,13.4)$ & $<0.001$ & 40.5 & $(38.9,42.2)$ & $<0.001$ \\
\hline & & Age & -2.2 & $(-2.8,-1.6)$ & $<0.001$ & 0.8 & $(0.2,1.4)$ & 0.008 & 0.6 & $(0.3,0.8)$ & $<0.001$ & -1.4 & $(-1.9,-0.8)$ & $<0.001$ \\
\hline & Mid-afternoon & Constant & 10.5 & $(9,12)$ & $<0.001$ & 57.7 & $(54.1,61.4)$ & $<0.001$ & 6.9 & $(5.7,8.2)$ & $<0.001$ & 35.4 & $(32.1,38.7)$ & $<0.001$ \\
\hline & & Age & -1.6 & $(-2.1,-1.1)$ & $<0.001$ & -1.4 & $(-2.6,-0.1)$ & 0.037 & 2.1 & $(1.6,2.5)$ & $<0.001$ & -0.7 & $(-1.9,0.5)$ & 0.231 \\
\hline & Dinner & Constant & 28.7 & $(26.5,31)$ & $<0.001$ & 46.7 & $(45,48.4)$ & $<0.001$ & 15.9 & $(14.7,17)$ & $<0.001$ & 37.4 & $(35.9,39)$ & $<0.001$ \\
\hline & & Age & -2.9 & $(-3.7,-2.2)$ & $<0.001$ & -0.7 & $(-1.3,-0.1)$ & 0.015 & 0.9 & $(0.5,1.3)$ & $<0.001$ & -0.2 & $(-0.7,0.4)$ & 0.572 \\
\hline & Late evening & Constant & 8.4 & $(6.5,10.3)$ & $<0.001$ & 53.8 & $(49.7,57.8)$ & $<0.001$ & 10.4 & $(8.8,12.1)$ & $<0.001$ & 35.8 & $(32.4,39.2)$ & $<0.001$ \\
\hline & & Age & 3.2 & $(2.6,3.8)$ & $<0.001$ & -2.5 & $(-3.8,-1.2)$ & $<0.001$ & 1.7 & $(1.1,2.2)$ & $<0.001$ & 0.8 & $(-0.3,2)$ & 0.138 \\
\hline & Extras & Constant & 1.2 & $(0.3,2.1)$ & 0.01 & 59.7 & $(53,66.4)$ & $<0.001$ & 5.2 & $(3.5,6.8)$ & $<0.001$ & 35 & $(28.8,41.2)$ & $<0.001$ \\
\hline & & Age & 2.4 & $(2.1,2.7)$ & $<0.001$ & -2.2 & $(-4.7,0.3)$ & 0.084 & 1 & $(0.4,1.7)$ & 0.001 & 1.2 & $(-1.2,3.5)$ & 0.338 \\
\hline \multirow[t]{14}{*}{ Girls $(n=3518)$} & Breakfast & Constant & 16.1 & $(14.8,17.5)$ & $<0.001$ & 61.5 & $(59.2,63.9)$ & $<0.001$ & 12.1 & $(11.3,12.9)$ & $<0.001$ & 26.4 & $(24.1,28.6)$ & $<0.001$ \\
\hline & & Age & -2.6 & $(-3.1,-2.2)$ & $<0.001$ & 1.5 & $(0.7,2.3)$ & $<0.001$ & 0.3 & $(0.1,0.6)$ & 0.019 & -1.8 & $(-2.6,-1.1)$ & $<0.001$ \\
\hline & Mid-morning & Constant & 6.3 & $(5.2,7.4)$ & $<0.001$ & 58 & $(54.5,61.6)$ & $<0.001$ & 5.3 & $(4.3,6.3)$ & $<0.001$ & 36.7 & $(33.3,40)$ & $<0.001$ \\
\hline & & Age & 2.9 & $(2.5,3.3)$ & $<0.001$ & -3.3 & $(-4.7,-2)$ & $<0.001$ & 1.5 & $(1.1,1.8)$ & $<0.001$ & 1.9 & $(0.6,3.2)$ & 0.003 \\
\hline & Lunch & Constant & 30.5 & $(28.9,32.1)$ & $<0.001$ & 46.3 & $(44.7,47.9)$ & $<0.001$ & 12.2 & $(11.5,12.9)$ & $<0.001$ & 41.6 & $(40.1,43.1)$ & $<0.001$ \\
\hline & & Age & -2.8 & $(-3.4,-2.2)$ & $<0.001$ & 0.5 & $(0,1.1)$ & 0.069 & 0.7 & $(0.4,0.9)$ & $<0.001$ & -1.2 & $(-1.7,-0.6)$ & $<0.001$ \\
\hline & Mid-afternoon & Constant & 9.5 & $(8,10.9)$ & $<0.001$ & 55.8 & $(52.4,59.1)$ & $<0.001$ & 6.8 & $(5.6,8)$ & $<0.001$ & 37.4 & $(34.4,40.4)$ & $<0.001$ \\
\hline & & Age & -1.7 & $(-2.2,-1.1)$ & $<0.001$ & -1.7 & $(-2.9,-0.4)$ & 0.011 & 1.6 & $(1.1,2)$ & $<0.001$ & 0.1 & $(-1.1,1.2)$ & 0.906 \\
\hline & Dinner & Constant & 27.6 & $(25.5,29.7)$ & $<0.001$ & 47.8 & $(46.1,49.5)$ & $<0.001$ & 15.8 & $(14.8,16.9)$ & $<0.001$ & 36.4 & $(34.8,37.9)$ & $<0.001$ \\
\hline & & Age & -2 & $(-2.7,-1.3)$ & $<0.001$ & 0 & $(-0.6,0.6)$ & 0.944 & 1.2 & $(0.8,1.6)$ & $<0.001$ & -1.2 & $(-1.7,-0.6)$ & $<0.001$ \\
\hline & Late evening & Constant & 8.8 & $(7.1,10.5)$ & $<0.001$ & 54.7 & $(51,58.4)$ & $<0.001$ & 10.5 & $(8.9,12.1)$ & $<0.001$ & 34.9 & $(31.8,38)$ & $<0.001$ \\
\hline & & Age & 3.3 & $(2.7,3.9)$ & $<0.001$ & -2 & $(-3.3,-0.7)$ & 0.003 & 1.8 & $(1.2,2.3)$ & $<0.001$ & 0.3 & $(-0.9,1.4)$ & 0.661 \\
\hline & Extras & Constant & 1.2 & $(0.4,2)$ & 0.005 & 66.3 & $(59.9,72.7)$ & $<0.001$ & 5.1 & $(3.5,6.6)$ & $<0.001$ & 28.7 & $(22.9,34.6)$ & $<0.001$ \\
\hline & & Age & 2.9 & $(2.6,3.2)$ & $<0.001$ & -1.5 & $(-4.2,1.1)$ & 0.261 & 0.1 & $(-0.5,0.8)$ & 0.641 & 1.4 & $(-1,3.8)$ & 0.250 \\
\hline
\end{tabular}

- Coefficient from linear mixed model adjusted for maternal education and child's BMI. 
Figure 2. Unadjusted means and $95 \% \mathrm{Cl}$ of macronutrient intake across different eating occasions in boys and girls at ages 10 and 13 years. Macronutrients expressed as percentage of energy consumed at a given eating occasion.

Within every eating occasion, a single * indicates a significant difference in the intake of a macronutrient between ages 10 and 13 years with a $p$-value $<0.01$. A double ${ }^{* *}$ indicates a significant difference in the intake of a macronutrient between ages 10 and 13 years with a $p$-value of $<0.001$. P-values derived from mixed linear models adjusted for maternal education and child's BMI.
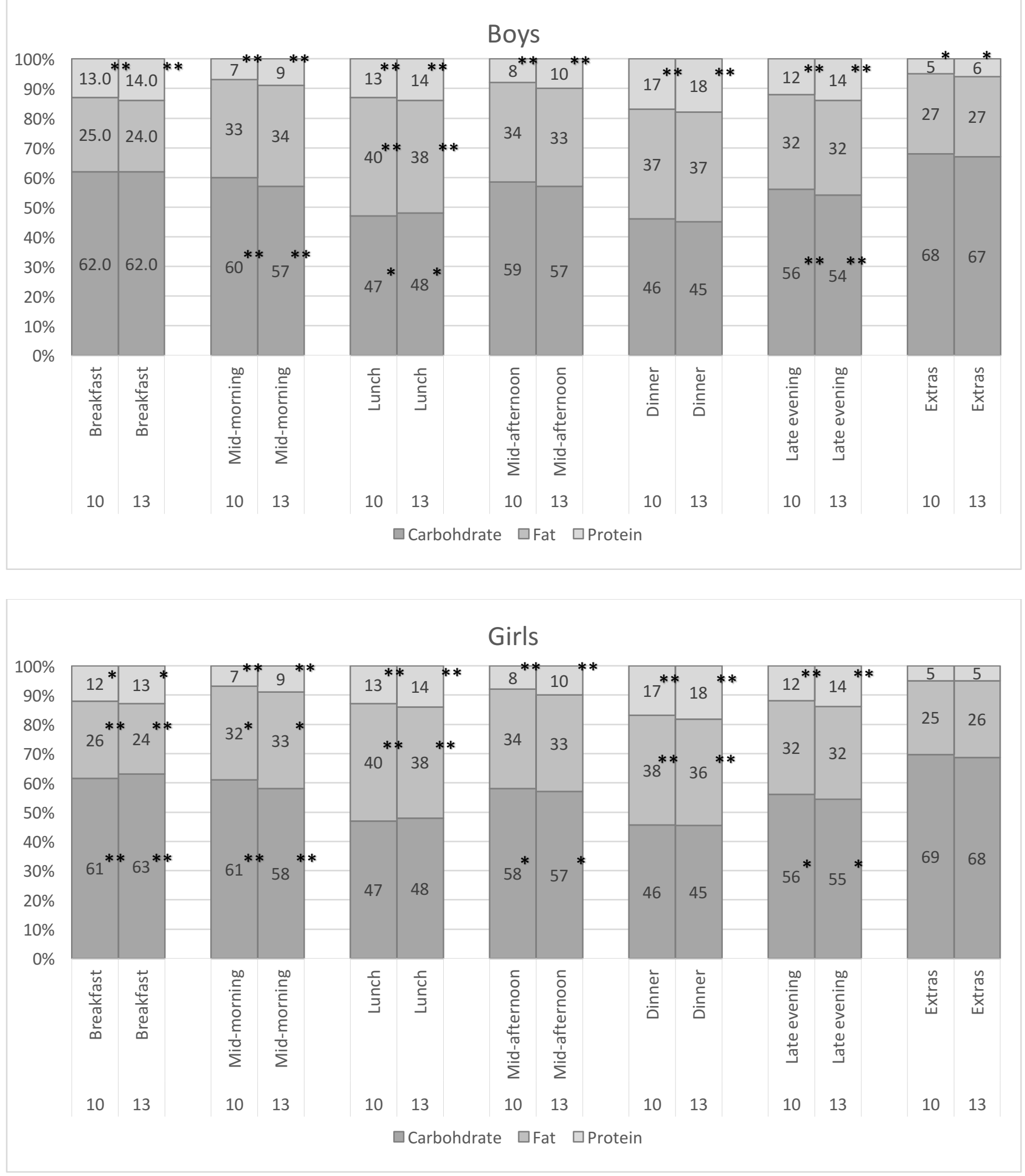